\title{
SNACK BAR RENDAH FOSFOR DAN PROTEIN BERBASIS PRODUK OLAHAN BERAS
}

\author{
Durotul Jauhariah, Fitriyono Ayustaningwarno ${ }^{*}$ \\ Program Studi Ilmu Gizi Fakultas Kedokteran Universitas Diponegoro \\ Jl.Dr.Sutomo No.14, Semarang, Telp (024) 8453708, Email : gizifk@undip.ac.id
}

\begin{abstract}
Background: Hyperphosphatemia is a metabolic disorder in chronic kidney disease patients. Nutritional strategies to decrease blood phosphate levels is to eat low phosphorus, protein, and phosphorus to protein ratio foods, such as rice and egg white. Snack modification like snack bar, use difference rice products and egg white can produce an attractive product with better nutrient content.

Objective: Analyzed the nutrient content, phosphorus to protein ratio, bulk density, breaking strength, and preference level of difference rice product in snack bar.

Method: The completely randomized single factor experimental design which is 3 types of rice products such as rice cereal, rice crispy, and pop rice. Preliminary research showed that snack bar with $20 \%$ egg white addition is the most preferred by panelists so it is used for primary research formulation. Primary research is making snack bar with difference rice products. The nutrient content, phosphorus to protein ratio, bulk density, and breaking strength analyzed use One Way ANOVA followed by Tukey and LSD test. Preference level analysis use Friedman followed by Wilcoxon test.

Results: The nutrient content of rice cereal formulation for each $45 \mathrm{~g}$ of serving is 194,78 kkal energy, 2,44 $\mathrm{g}$ protein, 58,13 $\mathrm{mg}$ phosphorus, and 23,74 $\mathrm{mg} / \mathrm{g}$ phosphorus to protein ratio. The rice crispy formulation contain 193,20 kkal energy, 2,61 g protein, 71,55 $\mathrm{mg}$ phosphorus, and 27,27 mg/g phosphorus to protein ratio. The pop rice formulation contain 202,66 kkal energy, 3,25 g protein, 77,77 $\mathrm{mg}$ phosphorus, and 23,80 $\mathrm{mg} / \mathrm{g}$ phosphorus to protein ratio. There is a significant difference between color and texture preferences but no significant on aroma and flavor of snack bar for each types.

Conclusion: All of snack bar formulation has qualified nutrient content and still can accepted by panelists. Recommended snack bar is rice cereal formulation.
\end{abstract}

Keyword : Hyperphosphatemia; nutrient content; phosphorus to protein ratio; rice product; egg white; snack bar

\begin{abstract}
ABSTRAK
Latar Belakang: Hiperfosfatemia merupakan gangguan metabolisme pada pasien gagal ginjal kronik. Strategi diet untuk menurunkan kadar fosfor dalam darah adalah mengonsumsi makanan rendah fosfor, protein dan rasio fosforprotein, antara lain beras dan putih telur. Modifikasi makanan selingan berupa snack bar menggunakan produk olahan beras dan putih telur dapat menghasilkan produk yang menarik dengan kandungan zat gizi lebih baik.

Tujuan: Menganalisis kandungan zat gizi, rasio fosfor-protein, densitas kamba, daya patah, serta tingkat kesukaan snack bar dengan berbagai produk olahan beras.

Metode: Penelitian eksperimental acak lengkap 1 faktor yaitu 3 jenis produk olahan beras meliputi sereal beras, rice krispi, dan brondong beras. Penelitian pendahuluan menunjukkan snack bar dengan penambahan putih telur $20 \%$ adalah yang paling disukai panelis sehingga digunakan sebagai formulasi tetap pada penelitian utama. Penelitian utama berupa pembuatan snack bar menggunakan berbagai produk olahan beras. Data kandungan zat gizi, rasio fosfor-protein, densitas kamba, dan daya patah dianalisis menggunakan uji One Way ANOVA dilanjutkan uji Tukey dan LSD. Tingkat kesukaan dianalisis menggunakan uji Friedman dilanjutkan uji Wilcoxon.

Hasil: Dalam berat takaran saji $45 \mathrm{~g}$, formulasi sereal beras mengandung 194, 78 kkal energi, 2,44 g protein, 58,13 $\mathrm{mg}$ fosfor, dan rasio fosfor-protein 23,74 mg/g. Formulasi rice krispi mengandung 193,20 kkal energi, 2,61 $\mathrm{g}$ protein, 71,55 mg fosfor, dan rasio fosfor-protein 27,27 mg/g. Formulasi brondong beras mengandung 202,66 kkal energi, 3,25 g protein, 77,77 mg fosfor, dan rasio fosfor-protein 23,80 mg/g. Terdapat perbedaan tingkat kesukaan panelis terhadap warna dan tekstur yang bermakna tetapi tidak pada aroma dan rasa snack bar.

Kesimpulan: Semua formulasi snack bar secara umum memenuhi syarat kandungan zat gizi dan masih dapat diterima oleh panelis. Formulasi snack bar yang direkomendasikan adalah sereal beras.
\end{abstract}

Kata kunci: Hiperfosfatemia; kandungan zat gizi; rasio fosfor-protein; produk olahan beras; putih telur; snack bar

${ }^{*}$ Penulis Penanggungjawab 


\section{PENDAHULUAN}

Penyakit gagal ginjal kronik (GGK) merupakan masalah kesehatan yang banyak dialami oleh masyarakat, baik di negara-negara maju maupun berkembang. Suatu penelitian melaporkan prevalensi penyakit GGK pada penduduk Indonesia yang tinggal di perkotaan dan kabupaten berkisar 8,6\%. ${ }^{1}$ Penurunan fungsi ginjal dapat menyebabkan gangguan metabolisme dalam tubuh, salah satunya hiperfosfatemia. Peningkatan kadar fosfor dalam darah terjadi seiring dengan menurunnya nilai laju filtrasi glomerulus (LFG), yaitu kurang dari $30 \mathrm{ml} / \mathrm{menit} / 1,73 \mathrm{~m}^{2}$ (stadium $4)^{2,3}$

Salah satu strategi untuk menurunkan kadar fosfor dalam darah adalah pembatasan asupan fosfor dan protein. Diet protein rendah berperan membantu mengendalikan asupan fosfor karena makanan sumber protein cenderung mengandung fosfor tinggi serta mengurangi hiperfiltrasi glomerulus sehingga kerusakan struktur sel epitel dan proteinuria dapat berkurang. ${ }^{4,5}$ Anjuran asupan fosfor dan protein untuk pasien GGK stadium 4 masing-masing adalah $800-1000 \mathrm{mg} /$ hari dan 0,6 gram $/ \mathrm{kg}$ berat badan/hari atau berkisar $8 \%$ dari kebutuhan energi sehari orang dewasa. ${ }^{2,6}$

Salah satu parameter yang dapat membantu pasien memilih bahan makanan sumber fosfor dan protein rendah adalah rasio fosfor-protein. Rasio rendah umumnya terdapat pada makanan sumber protein tetapi turut diikuti pula dengan kandungan fosfor dan proteinnya yang tinggi. ${ }^{7}$ Penelitian menunjukkan konsumsi makanan yang memiliki kandungan fosfor tinggi dan rasio fosfor-protein lebih dari $16 \mathrm{mg} /$ gram berhubungan dengan meningkatnya risiko kematian pada pasien GGK. ${ }^{8}$ Oleh karenanya, diperlukan alternatif bahan makanan selain sumber protein yang berasio rendah tetapi juga mengandung fosfor dan protein rendah, salah satunya sumber karbohidrat.

Beras merupakan salah satu sumber karbohidrat yang memiliki rasio fosfor-protein rendah $(9,6 \mathrm{mg} / \mathrm{gram}){ }^{9}$ Beras juga memiliki nilai biologis protein lebih tinggi dibandingkan dengan serealia lainnya yaitu $56 .{ }^{10}$ Konsumsi makanan yang bernilai biologis protein tinggi berperan dalam meningkatkan penyerapan nitrogen untuk sintesis protein sehingga mengurangi sisa hasil pemecahan protein dalam tubuh dan mengurangi beban kerja ginjal. ${ }^{4,6}$ Dalam 100 gram beras terkandung $357 \mathrm{kkal}$ energi, 8,4 gram protein, 1,7 gram lemak, 77,1 gram karbohidrat, $81 \mathrm{mg}$ fosfor, $147 \mathrm{mg}$ kalsium, $27 \mathrm{mg}$ natrium, dan $71 \mathrm{mg}$ kalium/ 100 gram. ${ }^{9}$ Nilai biologis fosfor beras termasuk rendah sehingga risiko peningkatan kadar fosfor dalam darah lebih rendah dibandingkan dengan sumber hewani. ${ }^{11,12}$ Beras juga merupakan sumber energi yang tinggi. Pemenuhan energi yang cukup, baik dari sumber karbohidrat maupun lemak dapat membantu mencegah terjadinya katabolisme protein sebagai energi sehingga meminimalkan sisa hasil metabolisme protein dan meningkatkan efisiensi penggunaan protein untuk pembentukan dan perbaikan jaringan tubuh. ${ }^{6}$

Olahan beras yang disajikan untuk pasien secara umum adalah nasi dan bubur. Pada stadium 4, pasien cenderung mengalami penurunan nafsu makan dan merasa bosan dengan sajian makanan yang kurang bervariasi. Untuk mengatasi hal tersebut, maka dapat dilakukan modifikasi sajian beras. Produk olahan beras yang saat ini populer di masyarakat adalah sereal beras, rice crispy, dan brondong beras. ${ }^{13,14}$ Ketiga produk tersebut memiliki bentuk bahan yang kompak, renyah, dan menarik untuk dikembangkan sebagai makanan selingan, salah satunya berupa snack bar.

Snack bar merupakan makanan ringan berbentuk batang dan umumnya dikonsumsi sebagai makanan selingan. Produksi snack bar sebagai makanan selingan untuk penderita penyakit kronik saat ini sedang dikembangkan oleh peneliti. $^{15}$ Hal ini dapat dipengaruhi oleh kemudahannya dalam mengolah dan memodifikasi bahan baku yang digunakan untuk pembuatan snack bar. Pemberian makanan selingan umumnya dalam porsi kecil dengan kandungan zat gizi berkisar 10\% dari kebutuhan energi sehari. Namun, produksi snack bar untuk pasien GGK di Indonesia masih jarang ditemukan sehingga pengembangan formulasi tersebut masih diperlukan.

Penambahan bahan pengikat berupa putih telur dapat menjadi alternatif pengganti sukrosa sehingga menghasilkan kandungan zat gizi snack bar yang lebih baik. Putih telur secara umum juga dianjurkan sebagai alternatif sumber protein yang baik untuk pasien GGK. Putih telur memiliki rasio fosfor-protein yang rendah $(1,4 \mathrm{mg} / \mathrm{gram})$ dan bernilai biologis protein tinggi (88). Walaupun Nilai biologis fosfor putih telur termasuk tinggi, tetapi turut diimbangi dengan kandungan fosfornya yang rendah sehingga risiko peningkatan kadar fosfor dalam darah pun lebih rendah dibandingkan dengan sumber hewani lainnya. ${ }^{7,11}$ Dalam 100 gram putih telur terkandung $52 \mathrm{kkal}$ energi, 10,9 gram protein, 0,17 gram lemak, 0,7 gram karbohidrat, $15 \mathrm{mg}$ fosfor, $7 \mathrm{mg}$ kalsium, $166 \mathrm{mg}$ natrium, dan $163 \mathrm{mg}$ kalium/ 100 gram. ${ }^{16}$ Berdasarkan latar belakang tersebut, maka 
dilakukan penelitian untuk menganalisis kandungan zat gizi, rasio fosfor-protein, densitas kamba, daya patah, dan tingkat kesukaan snack bar dengan berbagai produk olahan beras.

\section{METODA}

Penelitian yang dilakukan termasuk dalam bidang food production. Penelitian ini dilaksanakan pada Desember 2012 sampai Februari 2013. Pengujian kandungan zat gizi dilakukan di Pusat Studi Pangan dan Gizi Universitas Gadjah Mada Yogyakarta dan daya patah di Laboratorium Ilmu Pangan Fakultas Teknologi Pertanian Universitas Katolik Soegijapranata Semarang.

Penelitian ini merupakan penelitian eksperimental dengan rancangan acak lengkap satu faktor yaitu 3 jenis produk olahan beras sebagai bahan utama, meliputi (1) sereal beras (2) rice crispy, dan (3) brondong beras. Penelitian ini didahului dengan perlakuan penambahan bahan pengikat berupa putih telur sebanyak $20 \%, 30 \%$, dan $40 \%$ dari berat total formulasi snack bar untuk mengetahui persentase penambahan putih telur yang dapat mengikat bahan utama serta menghasilkan snack bar yang disukai oleh panelis. Penetapan persentase dilakukan dengan memasukkan variasi persentase tersebut ke dalam program software Microsoft Excel 2007 untuk dihitung kesesuaian kandungan zat gizinya dengan standar kandungan zat gizi per sajian makanan selingan dalam diet penyakit GGK dengan hiperfosfatemia, yaitu 4 gram protein, 6,7 gram lemak, 31 gram karbohidrat, $200 \mathrm{kkal}$ energi, dan $80 \mathrm{mg}$ fosfor. ${ }^{2,6}$ Standar ini ditetapkan berdasarkan kandungan kalori sehari per sajian snack bar yang ada di pasaran, yaitu 2000 kkal dan mempertimbangkan anjuran asupan zat gizi untuk pasien gagal ginjal kronik dengan hiperfosfatemia. Perhitungan standar kandungan zat gizi per sajian makanan selingan dapat dilihat pada Lampiran 1 . Kemudian persentase tersebut diuji coba pada brondong beras karena memiliki densitas kamba lebih kecil dibandingkan dengan bahan utama lainnya. Semakin kecil densitas kamba maka semakin besar jumlah bahan pengikat yang dibutuhkan untuk membentuk snack bar yang kompak. Apabila persentase tersebut dapat mengikat brondong beras maka bahan utama lainnya pun dapat terikat sehingga menghasilkan snack bar yang kompak. Snack bar dengan variasi persentase penambahan putih telur kemudian dinilai tingkat kesukaannya dengan uji 5 skala hedonik kepada panelis agak terlatih yaitu 20 orang mahasiswa Program Studi Ilmu Gizi Fakultas Kedokteran Universitas Diponegoro. Hasil penelitian pendahuluan menunjukkan snack bar dengan penambahan putih telur $20 \%$ adalah yang paling disukai oleh panelis sehingga digunakan sebagai formulasi tetap pada penelitian utama. Hasil analisis penelitian pendahuluan dapat dilihat pada Lampiran 2. Setiap formulasi pada penelitian utama dilakukan pengujian kandungan zat gizi secara duplo, rasio fosfor-protein, densitas kamba dan daya patah sebanyak tiga kali pengulangan, sedangkan penilaian tingkat kesukaan snack bar dilakukan satu kali tanpa pengulangan.

Pembuatan snack bar pada penelitian ini menggunakan 18 gram produk olahan beras, 5 gram minyak kelapa sawit, 8,3 gram putih telur dan 10 gram gula pasir. Kemudian dilakukan pencampuran, pencetakan dan pemanggangan adonan selama 55 menit dalam oven. Proses pembuatan snack bar dapat dilihat pada Lampiran 3. Sereal beras yang digunakan merupakan produk komersial Kellogg Limited-Thailand berupa sereal rice krispies vegetarian yang diolah melalui proses ekstrusi dengan komposisi tepung beras giling, gula, garam beriodium, ekstrak malt, vitamin $\mathrm{A}, \mathrm{C}$, B1, B2, B6, B12, niasin, dan asam folat, reduced iron (ferro), tokoferol, gluten, serta kacang kedelai. Bentuk sereal beras menyerupai butiran beras yang pipih, berwarna coklat muda, beraroma harum, bertekstur renyah dan berpasir, serta memiliki rasa manis. Rice crispy merupakan produk komersial yang diperoleh dari Toko Inti Sari-Yogyakarta yang diolah melalui proses ekstrusi dengan bahan baku dari tepung beras giling. Bentuk rice crispy menyerupai butiran beras, berwarna putih kekuningan, tidak beraroma, bertekstur padat dan keras, serta memiliki rasa yang hambar. Brondong beras hasil produksi industri rumahan, Tegal RejoAmbarawa yang diolah melalui proses ekstrusi (puffing gun) dengan bahan baku dari butiran beras C6. Brondong beras berbentuk butiran lonjong berukuran sekitar 3 kali lebih panjang dari rice crispy, berwarna putih, tidak beraroma, memiliki permukaan yang halus, bertekstur padat mengembang, serta memiliki rasa yang hambar.

Pada penelitian utama, data yang dikumpulkan adalah variabel terikat meliputi kandungan zat gizi, rasio fosfor-protein, densitas kamba, daya patah, dan tingkat kesukaan. Kandungan zat gizi yang dianalisis meliputi kadar protein yang diperoleh dengan metode kjeldahl (gram),${ }^{17}$ lemak diperoleh dengan metode soxhlet (gram),${ }^{17}$ karbohidrat diperoleh dengan metode by 
difference (gram), ${ }^{17}$ energi diperoleh dengan menjumlahkan kadar protein, lemak, dan karbohidrat (kkal), dan fosfor diperoleh dengan metode kolorimetri (Molibdat-Vanadat) (mg). ${ }^{17}$ Densitas kamba diperoleh dengan membandingkan berat kering dengan volume ruang $(\mathrm{gram} / \mathrm{ml})$, rasio fosfor-protein diperoleh dengan membandingkan kadar fosfor dan protein dalam snack bar $(\mathrm{mg} / \mathrm{gram}){ }^{7}$ daya patah diperoleh dengan instrumental The TA-XT2i Texture Analyzer LLOYD Instrumental $(\mathrm{N}),{ }^{18}$ dan tingkat kesukaan meliputi penilaian terhadap warna, aroma, tekstur, dan rasa diperoleh dengan uji 5 skala hedonik (1=Sangat Tidak Suka, 2=Tidak Suka, 3=Netral, 4=Suka, 5=Sangat Suka), ${ }^{19}$ kepada panelis agak terlatih yaitu 20 orang mahasiswa Program Studi Ilmu Gizi Fakultas Kedokteran Universitas Diponegoro.
Data yang terkumpul dianalisis menggunakan program komputer. Data densitas kamba, daya patah, rasio fosfor-protein, dan kandungan zat gizi dianalisis menggunakan uji One Way ANOVA dilanjutkan dengan uji Tukey untuk densitas kamba dan kadar protein serta LSD untuk kadar energi. Tingkat kesukaan dianalisis menggunakan uji Friedman dilanjutkan dengan uji Wilcoxon. Uji lanjut dilakukan untuk mengetahui perbedaan yang bermakna antar formulasi terhadap variabel yang diuji dengan derajat kepercayaan $95 \%$.

\section{HASIL}

\section{Kandungan Zat Gizi Bahan Utama}

Hasil rerata kandungan zat gizi bahan utama berupa berbagai produk olahan beras meliputi sereal beras, rice crispy, dan brondong beras dapat dilihat pada Tabel 1 .

Table 1. Rerata Kandungan Zat Gizi Per 100 Gram Bahan Utama

\begin{tabular}{|c|c|c|c|c|c|c|}
\hline \multirow[b]{2}{*}{ Jenis } & \multicolumn{5}{|c|}{ Rerata Kandungan Gizi } & \multirow{2}{*}{$\begin{array}{l}\text { Rasio } \\
\text { fosfor- } \\
\text { protein } \\
\text { (mg/gr) }\end{array}$} \\
\hline & $\begin{array}{l}\text { Protein } \\
\text { (gr) }\end{array}$ & $\begin{array}{c}\text { Lemak } \\
\text { (gr) }\end{array}$ & $\begin{array}{c}\text { Karbohidr } \\
\text { at } \\
\text { (gr) }\end{array}$ & $\begin{array}{c}\text { Energi } \\
\text { (kkal) }\end{array}$ & $\begin{array}{c}\text { Fosfor } \\
\text { (mg) }\end{array}$ & \\
\hline Sereal beras & $\begin{array}{c}5,73 \pm 0 \\
16\end{array}$ & $\begin{array}{c}0,45 \pm 0 \\
01\end{array}$ & $85,23 \pm 0,06$ & $\begin{array}{c}367,89 \pm 0 \\
49\end{array}$ & $\begin{array}{c}92,05 \pm 0,2 \\
1\end{array}$ & $16,06 \pm 0,47$ \\
\hline Rice crispy & $\begin{array}{c}6,91 \pm 0 \\
02\end{array}$ & $\begin{array}{c}1,26 \pm 0 \\
01\end{array}$ & $86,04 \pm 0,16$ & $\begin{array}{c}383,06 \pm 0 \\
26\end{array}$ & $\begin{array}{c}58,20 \pm 1,1 \\
3\end{array}$ & $8,43 \pm 0,13$ \\
\hline $\begin{array}{l}\text { Brondong } \\
\text { beras }\end{array}$ & $\begin{array}{c}7,60 \pm 0 \\
05\end{array}$ & $\begin{array}{c}0,32 \pm 0 \\
11\end{array}$ & $85,76 \pm 0,97$ & $\begin{array}{c}376,23 \pm 2 \\
72\end{array}$ & $\begin{array}{c}44,70 \pm 0,2 \\
8\end{array}$ & $5,89 \pm 0,07$ \\
\hline
\end{tabular}

Produk olahan beras yang memiliki kandungan protein terendah adalah sereal beras $(5,73$ gram $/ 100$ gram). Kadar fosfor terendah terkandung dalam brondong beras $(44,7 \mathrm{mg} / 100$ gram $)$ diiringi dengan rasio fosfor-protein terendah $(5,88 \mathrm{mg} / \mathrm{gram})$. Rice crispy memiliki kandungan energi tertinggi (383,06 kkal/100 gram).

\section{Densitas Kamba}

Densitas kamba merupakan sifat fisik yang menunjukkan kepadatan bahan atau perbandingan berat bahan terhadap volumenya. Nilai densitas kamba berhubungan dengan daya serap minyak dan buih putih telur sehingga berpengaruh terhadap kandungan zat gizi, daya patah, dan tingkat kesukaan snack bar. Hasil analisis densitas kamba bahan utama dan formulasi snack bar dapat dilihat pada Lampiran 8 dan secara singkat pada Tabel 2. Hasil analisis menunjukkan terdapat perbedaan bermakna antar jenis bahan utama maupun antar formulasi snack bar.

Table 2. Hasil Analisis Densitas Kamba

\begin{tabular}{ccc}
\hline \multirow{2}{*}{ Formula } & \multicolumn{2}{c}{ Densitas Kamba $($ gram/ml $)$} \\
\cline { 2 - 3 } & Bahan Utama & Snack Bar \\
\hline Sereal beras & $0,23 \pm 1,10^{-4 \mathrm{a}}$ & $0,43 \pm 3,10^{-4 \mathrm{a}}$ \\
Rice crispy & $0,15 \pm 5,10^{-5} \mathrm{~b}$ & $0,40 \pm 1,10^{-4} \mathrm{~b}$ \\
Brondong beras & $0,06 \pm 1,10^{-4 \mathrm{c}}$ & $0,22 \pm 1,10^{-4 \mathrm{c}}$ \\
& $\mathrm{p}=0,000$ & $\mathrm{p}=0,000$ \\
\hline
\end{tabular}


Keterangan: Angka yang diikuti dengan huruf superscript berbeda $(a, b, c)$ menunjukkan perbedaan yang bermakna

3. Kandungan Zat Gizi Snack Bar

Hasil analisis kandungan zat gizi snack bar dapat dilihat pada Lampiran 9 dan secara singkat pada Tabel 3.

Table 3. Hasil Analisis Kandungan Zat Gizi Per 100 Gram Snack Bar

\begin{tabular}{|c|c|c|c|c|c|c|}
\hline \multirow[b]{2}{*}{ Formula } & \multicolumn{5}{|c|}{ Kandungan Gizi } & \multirow{2}{*}{$\begin{array}{c}\text { Rasio } \\
\text { fosfor- } \\
\text { protein } \\
\text { (mg/gr) }\end{array}$} \\
\hline & $\begin{array}{l}\text { Protein } \\
\quad \text { (gr) }\end{array}$ & $\begin{array}{c}\text { Lemak } \\
\text { (gr) }\end{array}$ & $\begin{array}{c}\text { Karbohidr } \\
\text { at } \\
\text { (gr) }\end{array}$ & $\begin{array}{c}\text { Energi } \\
\text { (kkal) }\end{array}$ & $\begin{array}{c}\text { Fosfor } \\
\text { (mg) }\end{array}$ & \\
\hline Sereal beras & $5,43 \pm 0,14^{\mathrm{a}}$ & $12,90 \pm 1,14$ & $73,76 \pm 1,31$ & $\underset{\mathrm{a}}{432,84 \pm 7,90}$ & $\begin{array}{c}129,17 \pm 46 \\
16\end{array}$ & $23,74 \pm 8,15$ \\
\hline Rice crispy & $5,80 \pm 0,38^{\mathrm{a}}$ & $11,71 \pm 0,90$ & $75,19 \pm 1,23$ & $\begin{array}{c}429,33 \pm 12,1 \\
4^{\mathrm{a}}\end{array}$ & $\begin{array}{c}159,00 \pm 35 \\
51\end{array}$ & $27,27 \pm 4,66$ \\
\hline $\begin{array}{c}\text { Brondong } \\
\text { beras }\end{array}$ & $\begin{array}{c}7,23 \pm 0,18^{b} \\
p=0,000\end{array}$ & $\begin{array}{c}13,57 \pm 0,44 \\
p=0,099\end{array}$ & $\begin{array}{c}74,82 \pm 0,37 \\
p=0,302\end{array}$ & $\begin{array}{c}450,36 \pm 2,16 \\
\mathrm{~b}=0,047\end{array}$ & $\begin{array}{c}172,83 \pm 51 \\
44 \\
\mathrm{p}=0,0515\end{array}$ & $\begin{array}{c}23,80 \pm 6,46 \\
p=0,763\end{array}$ \\
\hline
\end{tabular}

Keterangan: Angka yang diikuti dengan huruf superscript berbeda $(a, b)$ menunjukkan perbedaan yang bermakna

Hasil analisis menunjukkan tidak terdapat perbedaan bermakna pada kandungan lemak, karbohidrat, fosfor, dan rasio fosforprotein kecuali formulasi brondong beras yang menunjukkan perbedaan kandungan protein dan energi yang bermakna dengan kedua formulasi lainnya.

\section{Daya Patah Snack Bar}

Hasil analisis daya patah dapat dilihat pada Lampiran 11 dan secara singkat pada Tabel 4. Perbedaan jenis produk olahan beras menghasilkan daya patah yang berbeda-beda meskipun secara statistik tidak menunjukkan adanya perbedaan yang bermakna antar formulasi.

Tabel 4. Hasil Analisis Daya Patah Snack Bar

\begin{tabular}{cc}
\hline Formula & Daya patah $(\mathbf{N})$ \\
\hline Sereal beras & $8,91 \pm 1,68$ \\
Rice crispy & $13,95 \pm 4,49$ \\
Brondong beras & $19,60 \pm 8,10$ \\
& $\mathrm{p}=0,131$ \\
\hline
\end{tabular}

\section{Tingkat Kesukaan Snack Bar}

Hasil analisis tingkat kesukaan snack bar dapat dilihat pada Lampiran 12 dan secara singkat pada Tabel 5. Hasil analisis menunjukkan terdapat perbedaan bermakna pada tingkat kesukaan panelis terhadap warna dan tekstur tetapi tidak bermakna pada aroma dan rasa snack bar.

Tabel 5. Hasil Analisis Tingkat Kesukaan Panelis Terhadap Snack Bar

\begin{tabular}{|c|c|c|c|c|c|c|c|c|}
\hline \multirow{2}{*}{ Formula } & \multicolumn{2}{|c|}{ Warna } & \multicolumn{2}{|c|}{ Aroma } & \multicolumn{2}{|c|}{ Tekstur } & \multicolumn{2}{|c|}{ Rasa } \\
\hline & Rerata & Ket & Rerata & Ket & Rerata & Ket & Rerata & Ket \\
\hline Sereal beras & $2,50 \pm 0,95^{\mathrm{a}}$ & Netral & $\begin{array}{c}3,85 \pm 0,5 \\
9\end{array}$ & Suka & $3,25 \pm 0,64^{\mathrm{a}}$ & Netral & $\begin{array}{c}4,05 \pm 0,6 \\
9\end{array}$ & Suka \\
\hline Rice crispy & $3,80 \pm 0,83^{b}$ & Suka & $\begin{array}{c}3,15 \pm 0,9 \\
9\end{array}$ & Netral & $3,15 \pm 0,99^{\mathrm{a}}$ & Netral & $\begin{array}{c}3,35 \pm 0,7 \\
5\end{array}$ & $\begin{array}{c}\text { Netra } \\
1\end{array}$ \\
\hline $\begin{array}{c}\text { Brondong } \\
\text { beras }\end{array}$ & $3,85 \pm 0,81^{b}$ & Suka & $\begin{array}{c}3,90 \pm 0,9 \\
7\end{array}$ & Suka & $4,2 \pm 0,77^{b}$ & Suka & $\begin{array}{c}3,95 \pm 0,8 \\
9\end{array}$ & Suka \\
\hline
\end{tabular}




$$
\begin{array}{ccc}
\mathrm{p}=0,000 & \mathrm{p}=0,083 & \mathrm{p}= \\
& & 0,083
\end{array}
$$

Keterangan: Angka yang diikuti dengan huruf superscript berbeda $(a, b)$ menunjukkan perbedaan yang bermakna

\section{PEMBAHASAN}

\section{Kandungan Zat Gizi Snack Bar}

Hiperfosfatemia terjadi seiring dengan menurunnya LFG dan umumnya dialami oleh pasien GGK stadium 4. ${ }^{2}$ Pada stadium tersebut, pasien cenderung mengalami penurunan nafsu makan yang berisiko terjadinya kekurangan zat gizi dan berlanjut pada malnutrisi. ${ }^{20}$ Untuk membantu pemenuhan tersebut, maka diperlukan penerapan porsi makan kecil tetapi sering, salah satunya dengan memberikan makanan selingan.

Standar kandungan protein untuk sekali penyajian makanan selingan pasien GGK dengan hiperfosfatemia yang dianjurkan maksimal adalah 4 gram sehingga diperoleh takaran saji snack bar sebesar 45 gram. Berat satu batang snack bar diketahui berkisar 15-25 gram sehingga dalam satu takaran saji dapat dikonsumsi 2-3 batang. Kadar protein dalam satu takaran saji sudah memenuhi standar makanan selingan pasien, yaitu berkisar 2,443,25 gram/45 gram. Diet protein rendah pada pasien GGK dengan hiperfosfatemia berperan membantu mengendalikan kadar fosfor karena makanan sumber protein juga mengandung fosfor tinggi serta menurunkan hiperfiltrasi yaitu dengan mengurangi beban asam amino yang melewati glomerulus sehingga mengurangi risiko terjadinya kerusakan sel epitel dan proteinuria. ${ }^{4,5}$

Putih telur merupakan sumber protein bernilai biologis tinggi karena memiliki kandungan asam amino yang cukup lengkap. Perhitungan menggunakan data USDA 2011 menunjukkan penambahan 8,3 gram putih telur yang mengandung lisin tinggi $(66,90$ $\mathrm{mg}$ ) dalam setiap batang snack bar dapat melengkapi kandungan asam amino beras yang memiliki keterbatasan lisin $(42,30 \mathrm{mg})$ sehingga meningkat menjadi $(109,20 \mathrm{mg}) .{ }^{16}$ Nilai biologis protein tergantung pada kelengkapan asam amino yang terkandung dalam makanan. Semakin lengkap kandungan asam amino esensial suatu makanan maka semakin tinggi nilai biologis protein. Kelengkapan asam amino tersebut menyebabkan lebih banyaknya nitrogen yang dapat diserap oleh tubuh untuk proses pembentukan dan pemeliharaan jaringan tubuh. Konsumsi makanan yang bernilai biologis protein tinggi berperan dalam meningkatkan efisiensi penyerapan nitrogen untuk sintesis protein sehingga mengurangi sisa hasil pemecahan protein dalam tubuh dan menurunkan beban kerja ginjal., ${ }^{4,6}$

Standar kandungan lemak untuk sekali penyajian makanan selingan pasien GGK dengan hiperfosfatemia yang dianjurkan adalah 6,7 gram. Berdasarkan hasil penelitian, kadar lemak dalam satu takaran saji snack bar berkisar 5,27-6,11 gram/45 gram. Kandungan lemak dalam snack bar sebagian besar berasal dari minyak kelapa sawit. Setelah dilakukan pengolahan, terjadi peningkatan kadar lemak dengan formulasi brondong beras sebagai snack bar yang mengandung lemak tertinggi, yaitu 13,57 gram/100 gram. Hal ini dapat dipengaruhi oleh densitas kamba butiran brondong beras yang lebih rendah dibandingkan dengan bahan utama lainnya.

Hasil pengukuran densitas kamba pada masing-masing bahan utama menunjukkan brondong beras memiliki densitas kamba rendah $(0,06$ gram $/ \mathrm{ml})$. Hal ini menunjukkan ukuran rongga butiran brondong beras yang kecil, jumlah rongga lebih banyak, dan dinding rongga yang tipis sehingga minyak dapat terserap sepenuhnya ke dalam butiran dan meningkatkan kadar lemak dalam snack bar. Berbeda dengan rice crispy dan sereal beras yang berdensitas kamba tinggi $(0,15-0,23 \mathrm{gram} / \mathrm{ml})$ menunjukkan ukuran rongga yang besar, jumlah rongga lebih sedikit, dan dinding rongga butiran yang tebal. Hal ini menyebabkan minyak tidak dapat terserap sepenuhnya ke dalam butiran dan cenderung meluber ke luar adonan sehingga menghasilkan kadar lemak lebih rendah dibandingkan formulasi brondong beras. ${ }^{21}$

Standar kandungan karbohidrat untuk sekali penyajian makanan selingan pasien GGK dengan hiperfosfatemia yang dianjurkan adalah 31 gram. Berdasarkan hasil penelitian, kadar karbohidrat dalam satu takaran saji snack bar berkisar 33,20-33.84 gram/45 gram. Kadar karbohidrat yang tinggi dapat 
disebabkan oleh kandungan karbohidrat mulamula setiap jenis produk olahan beras yang tinggi serta adanya pemberian sukrosa pada proses pengocokan putih telur. Karbohidrat berperan dalam penentuan karakteristik makanan seperti sukrosa yang menimbulkan rasa manis dan terjadinya reaksi pencoklatan non enzimatis (maillard) antara gula pereduksi dan asam amino yang menghasilkan warna coklat dan aroma karamel pada produk. $^{22}$

Standar kandungan energi untuk sekali penyajian makanan selingan pasien GGK dengan hiperfosfatemia yang dianjurkan adalah 200 kkal. Hasil penelitian menunjukkan kandungan energi dalam satu takaran saji snack bar berkisar 193,20-202,66 $\mathrm{kkal} / 45$ gram. Pemenuhan asupan protein, lemak dan karbohidrat yang cukup, penting untuk membantu menyediakan energi dalam menjalankan setiap aktifitas, mempertahankan berat badan yang sesuai serta menjaga penggunaan protein untuk pembentukan dan perbaikan jaringan tubuh sehingga dapat meminimalkan hasil sisa metabolisme protein yang dapat memperberat kerja ginjal pasien. ${ }^{6,23}$

Standar kandungan fosfor untuk sekali penyajian makanan selingan pasien GGK dengan hiperfosfatemia yang dianjurkan maksimal adalah $80 \mathrm{mg}$. Berdasarkan hasil penelitian, kadar fosfor dalam satu takaran saji snack bar sudah memenuhi standar tersebut, yaitu berkisar 58,13-77,77 mg/45 gram. Pembatasan asupan fosfor berperan dalam membantu menurunkan kadar fosfor dalam tubuh serta mencegah terjadinya kalsifikasi pembuluh darah sehingga menurunkan risiko penyakit kardiovaskuler pada pasien GGK. ${ }^{2}$

Hasil penelitian menunjukkan terjadinya peningkatan kadar fosfor dari $44,70-92,05 \mathrm{mg} / 100$ gram produk olahan beras menjadi 129,17-172,83 mg/100 gram snack bar. Rendahnya kadar fosfor dalam produk olahan beras dapat disebabkan oleh tidak terdeteksinya asam fitat sebagai bentuk simpanan fosfor dalam biji-bijian. ${ }^{24}$ Kadar fosfor brondong beras lebih rendah dibandingkan produk olahan beras lainnya. Hal ini dapat dipengaruhi oleh bahan pembuatan brondong beras yang masih berupa butiran beras sehingga berkemungkinan mengandung asam fitat lebih tinggi dibandingkan bahan baku sereal beras dan rice crispy yang telah melalui proses penepungan menjadi tepung beras.

Kadar fosfor snack bar yang tinggi dapat dipengaruhi oleh adanya penambahan buih putih telur. Setelah dilakukan pengolahan, kadar fosfor tertinggi terkandung dalam formulasi brondong beras yaitu 172,83 $\mathrm{mg} / 100$ gram. Peningkatan kadar fosfor tersebut dapat disebabkan adanya aktivasi enzim fitase dalam brondong beras oleh $\mathrm{pH}$ basa putih telur selama proses pencampuran dan pencetakan adonan. Enzim fitase aktif pada $\mathrm{pH}$ 3,5-8 sedangkan $\mathrm{pH}$ telur berkisar 7,6. Enzim fitase dalam keadaan aktif akan menghidrolisis asam fitat menjadi asam fosfat sehingga meningkatkan ketersediaan dan bioavailabilitas fosfor dalam snack bar. ${ }^{24,25}$

Salah satu cara untuk meminimalkan peningkatan kadar fosfor tersebut adalah dengan menambahkan bahan pengikat alternatif lain seperti inulin. Inulin merupakan salah satu functional fiber yang terdiri atas polimer-polimer fruktosa yang terkandung dalam bahan makanan. ${ }^{6}$ Inulin memiliki sifat daya ikat yang baik sehingga pemberiannya dalam formulasi snack bar dapat meminimalkan penggunaan atau menggantikan buih putih telur. Suatu penelitian menunjukkan konsumsi inulin dan oligosakarida dapat membantu menurunkan beban kerja ginjal dengan mengurangi terjadinya uremia dengan meningkatkan ekskresi nitrogen melalui feses. ${ }^{26}$ Penelitian menunjukkan konsumsi oligofruktosa 15 gram/hari selama 15 hari dan dilanjutkan dengan inulin 15 gram/hari pada 15 hari berikutnya dapat meningkatkan ekskresi nitrogen melalui feses pada orang sehat. ${ }^{27}$

\section{Rasio Fosfor-Protein Snack Bar}

Dalam diet GGK dengan hiperfosfatemia, rasio fosfor-protein berfungsi sebagai parameter yang membantu pasien dalam memilih makanan yang mengandung fosfor dan protein rendah. Suatu penelitian menunjukkan pasien GGK yang mengonsumsi makanan berasio rendah $(\leq 16 \mathrm{mg} / \mathrm{gram})$ memiliki risiko kematian yang lebih rendah dibandingkan dengan makanan yang berasio lebih tinggi. ${ }^{8}$ Hasil penelitian menunjukkan rasio fosfor-protein snack bar berkisar 23,74$27,27 \mathrm{mg} / \mathrm{gram}$. Meskipun rasio snack bar tersebut lebih tinggi, tetapi turut diimbangi 
dengan kandungan fosfornya yang rendah dan masih dibawah standar maksimal per sajian makanan selingan $(80 \mathrm{mg})$ sehingga menurunkan risiko peningkatan kadar fosfor dalam darah.

Dalam aplikasinya, rasio fosforprotein ini tidak dapat digunakan secara terpisah tanpa mempertimbangan kadar dan nilai biologis fosfor dan protein yang terkandung dalam makanan tersebut. Rasio rendah terdapat pada makanan sumber hewani, yakni sebagai sumber protein yang bernilai biologis protein tinggi tetapi turut diikuti dengan kandungan dan nilai biologis fosfornya yang tinggi. ${ }^{7}$ Suatu penelitian menunjukkan seseorang yang mengonsumsi makanan bernilai biologis fosfor tinggi (sumber hewani) memiliki risiko peningkatan kadar fosfor lebih tinggi dibandingkan dengan makanan yang bernilai biologis fosfor rendah (sumber nabati). ${ }^{12}$

Penggunaan rasio fosfor-protein juga perlu memperhatikan porsi asupan makanan tersebut. Meskipun rasio fosfor-protein tidak terpengaruh oleh porsi, tetapi kadar fosfor dan protein yang terkandung dalam makanan tersebut sangat dipengaruhi oleh porsi. Oleh karenanya, konsumsi makanan yang berasio rendah pun tetap perlu memperhatikan porsi yang diasup karena konsumsi berlebihan secara berkepanjangan dapat berisiko menyebabkan kelebihan asupan fosfor. ${ }^{7}$

\section{Daya Patah Snack Bar}

Hasil penelitian menunjukkan daya patah snack bar dengan variasi olahan beras berkisar 8,91-19,60 $\mathrm{N}$ dengan formulasi sereal beras sebagai snack bar yang paling mudah dipatahkan. Daya patah tergantung pada karakteristik tekstur produk. Snack bar yang bertekstur lebih lembut akan menghasilkan titik puncak yang lebih rendah dibandingkan yang bertekstur keras.

Penelitian sebelumnya menunjukkan semakin rendah nilai tekanan maka semakin kecil gaya yang dikeluarkan untuk mematahkan snack bar. ${ }^{28}$ Dalam aplikasinya, daya patah dapat diasumsikan sebagai besar gaya yang dikeluarkan untuk mengunyah snack bar. ${ }^{29}$ Semakin mudah dipatahkan maka berkemungkinan pula semakin mudahnya pasien mengunyah snack bar tersebut.

Daya patah dapat dipengaruhi oleh persentase kadar air, bahan pengikat, dan karakteristik bahan baku yang digunakan. Semakin tinggi kadar air maka semakin rendah daya patah yang dihasilkan karena tekstur snack bar menjadi lebih lembut atau lembek. Hal ini disebabkan oleh terserapnya air ke dalam butiran produk beras sehingga dinding rongga tidak lagi kaku tetapi menjadi lentur dan lembek serta mudah hancur. ${ }^{30}$ Semakin besar persentase penambahan buih putih telur sebagai bahan pengikat maka semakin kecil daya patah yang dihasilkan. Tingginya persentase buih putih telur yang diberikan akan meningkatkan kadar air sehingga menghasilkan tekstur yang lembut. Penelitian menunjukkan semakin besar densitas kamba maka semakin kecil persentase larutan bahan pengikat yang diperlukan untuk membentuk snack bar yang kompak. ${ }^{31}$ Densitas kamba berhubungan dengan daya patah snack bar, seperti pada gambar 1.
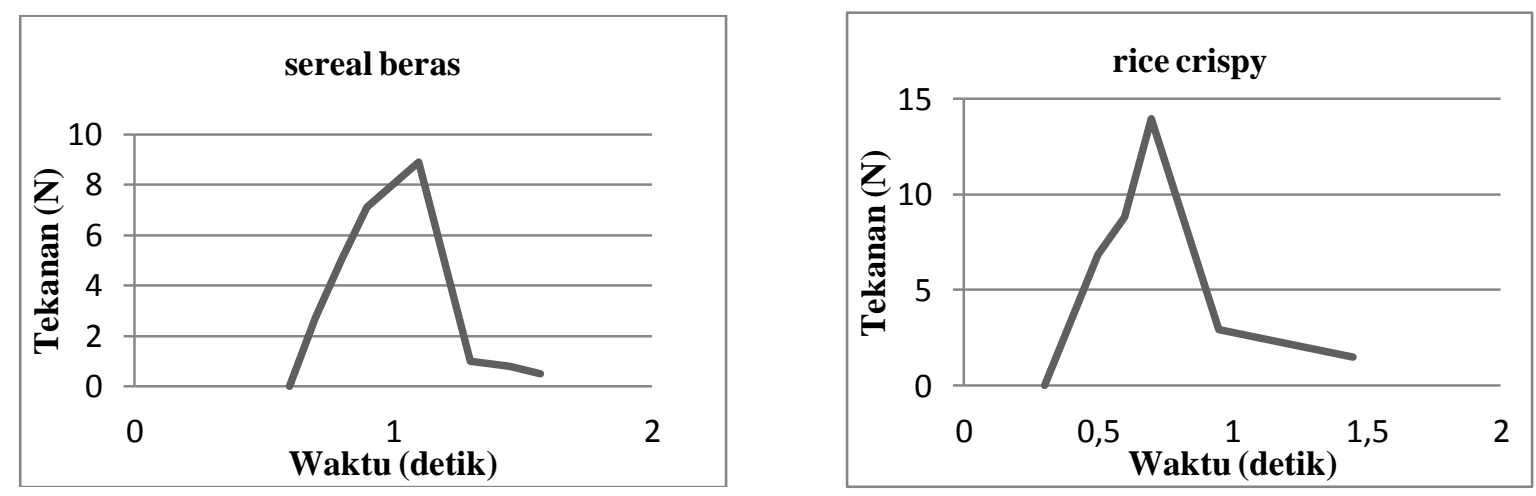


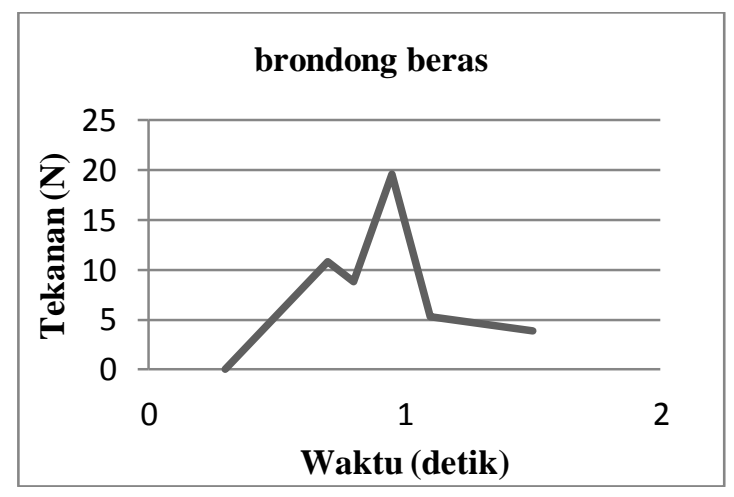

Gambar 1. Grafik uji daya patah snack bar

Semakin banyak titik patah yang dihasilkan oleh snack bar, maka semakin rendah densitas kamba snack bar sedangkan semakin sedikit titik patah yang dihasilkan, maka semakin tinggi densitas kamba snack bar. ${ }^{21}$ Kelemahan pengukuran daya patah snack bar menggunakan instrumental texture analyzer pada penelitian ini adalah tidak sama ratanya tebal dan tekstur snack bar. Perbedaan tebal snack bar dipengaruhi oleh daya susut yang berbeda-beda antar formulasi serta kesulitan peneliti untuk menata setiap butiran produk beras agar tertata rapat dan rapi. Perbedaan formulasi sereal beras yang bertekstur lebih lembut dibandingkan kedua formulasi lainnya yang bertekstur renyah. Kedua hal tersebut kemudian dapat mempengaruhi nilai daya patah yang tidak seragam di setiap pengulangan.

\section{Tingkat Kesukaan Snack Bar}

Perbedaan jenis produk olahan beras yang digunakan sebagai bahan utama snack bar akan menghasilkan warna dan tingkat kesukaan yang berbeda-beda. Warna snack bar yang dihasilkan adalah putih kecoklatan pada formulasi brondong beras, kuning keemasan pada rice crispy, dan coklat tua pada formulasi sereal beras. Hasil penelitian menunjukkan warna setiap formulasi snack bar mendapatkan penilaian suka, kecuali formulasi sereal beras yang mendapatkan penilaian netral. Hal ini disebabkan oleh formulasi sereal beras yang berwarna lebih gelap dibandingkan dengan formulasi lainnya serta adanya lapisan putih pada permukaan yang menyebabkan tidak meratanya warna snack bar.

Penggunaan sereal beras pada formulasi snack bar akan menghasilkan warna coklat tua. Warna tersebut didapatkan dari warna mula-mula sereal beras yang disebabkan oleh reaksi maillard selama proses ekstrusi. ${ }^{22}$ Lapisan putih pada permukaan snack bar didapatkan dari warna buih putih telur yang tidak terserap sepenuhnya ke dalam butir sereal beras karena memiliki densitas kamba yang besar. Perbedaaan kedua warna tersebut kemudian menyebabkan tidak meratanya warna formulasi sereal beras. Pembentukan lapisan buih putih telur juga terjadi pada permukaan formulasi rice crispy. Namun, warna mula-mula rice crispy yang putih kekuningan cenderung dapat menyatu dengan warna putih yang dihasilkan oleh buih putih telur sehingga tidak menimbulkan perbedaan warna yang bermakna.

Tingkat kesukaan panelis terhadap aroma snack bar menunjukkan setiap formulasi mendapatkan penilaian suka, kecuali formula rice crispy yang mendapatkan penilaian netral. Hal ini disebabkan adanya aroma tengik yang samar pada formulasi rice crispy dibandingkan formulasi lainnya, yaitu sereal beras dan brondong beras yang beraroma karamel.

Aroma tengik yang samar tersebut terjadi pada formulasi yang memiliki densitas kamba tinggi. Hal ini menyebabkan tidak terserapnya minyak secara sepenuhnya ke dalam butir sehingga cenderung meluber ke luar adonan. Hal ini kemudian menyebabkan terjadinya autooksidasi asam lemak tidak jenuh saat pemangangan adonan. ${ }^{22}$ Namun, aroma tengik pada formulasi sereal beras tidak setajam pada rice crispy karena tertutup oleh aroma ekstrak malt dan tepung kacang kedelai yang terkandung dalam sereal beras sedangkan rice crispy hanya terbuat dari tepung beras saja. 
Tingkat kesukaan panelis terhadap tekstur snack bar menunjukkan formulasi brondong beras mendapatkan penilaian tertinggi yaitu suka, sedangkan kedua formulasi lainnya mendapatkan penilaian netral. Hal ini disebabkan oleh tekstur formulasi brondong beras yang lebih renyah dibandingkan dengan sereal beras yang lengket dan rice crispy yang keras.

Tekstur formulasi brondong beras yang renyah dapat dipengaruhi oleh karakteristik butiran brondong beras yang memiliki densitas kamba kecil sehingga pemberian minyak dan buih putih telur dapat terserap secara keseluruhan ke dalam butir dan membentuk tekstur yang keras tetapi cukup renyah untuk dikonsumsi. Formulasi rice crispy memiliki tekstur yang lebih keras dibandingkan dengan brondong beras meskipun uji daya patah brondong beras lebih tinggi dibandingkan rice crispy. Hal ini dapat disebabkan oleh kandungan pati rice crispy yang lebih tinggi serta adanya perbedaan tebal dan penataaan butiran produk beras yang tidak merata. ${ }^{18}$ Penggunaan sereal beras pada formulasi snack bar menghasilkan tekstur yang lengket karena adanya reaksi karamelisasi sukrosa yang terkandung dalam sereal beras dan buih putih telur. ${ }^{22}$

Rasa setiap formulasi snack bar secara umum adalah manis. Tingkat kesukaan panelis terhadap rasa snack bar menunjukkan formulasi sereal beras dan brondong beras mendapatkan penilaian suka, sedangkan formulasi rice crispy mendapatkan penilaian netral. Rasa manis disebabkan oleh kandungan sukrosa pada formulasi snack bar. Dalam aplikasinya, sukrosa berperan sebagai bahan pemanis dan pengikat serta dapat membantu meningkatkan kandungan energi snack bar. ${ }^{6,22}$

\section{Rekomendasi Snack Bar}

Snack bar yang direkomendasikan sebagai alternatif makanan selingan untuk pasien GGK dengan hiperfosfatemia adalah formulasi sereal beras. Hal ini disebabkan oleh formulasi sereal beras memiliki kandungan zat gizi dan rasio fosfor-protein yang paling mendekati standar per sajian makanan selingan serta masih dapat diterima oleh panelis.

Tabel 6. Rekapitulasi Kandungan Zat Gizi Per Takaran Saji Snack Bar (45 Gram)

\begin{tabular}{ccccc}
\hline $\begin{array}{c}\text { Kandungan zat } \\
\text { gizi }\end{array}$ & $\begin{array}{c}\text { Standar } \\
\text { kandungan zat } \\
\text { gizi }\end{array}$ & $\begin{array}{c}\text { Sereal } \\
\text { beras }\end{array}$ & Rice crispy & $\begin{array}{c}\text { Brondong } \\
\text { beras }\end{array}$ \\
\hline Protein (gr) & maksimal 4 & $2,44 \pm 0,06$ & $2,61 \pm 0,17$ & $3,25 \pm 0,08$ \\
Lemak (gr) & 6.7 & $5,80 \pm 0,51$ & $5,27 \pm 0,40$ & $6,11 \pm 0,20$ \\
Karbohidrat (gr) & 31 & $33,20 \pm$ & $33,84 \pm 0,55$ & $33,67 \pm 0,17$ \\
& & 0,59 & & \\
Energi (kkal) & 200 & $194,78 \pm$ & $193,20 \pm$ & $202,66 \pm 0,97$ \\
& & 3,55 & 5,46 & \\
Fosfor (mg) & maksimal 80 & $58,13 \pm$ & $71,55 \pm$ & $77,78 \pm 23,15$ \\
& & 20,78 & 15,98 & \\
RPP (mg/gr) & $\leq 16$ & $23,74 \pm$ & $27,27 \pm 4,66$ & $23,80 \pm 6,46$ \\
& & 8,14 & & \\
\hline
\end{tabular}

Beberapa hal yang menyebabkan produk snack bar lebih direkomendasikan dibandingkan dalam bentuk bahan utama adalah (1) snack bar merupakan produk makanan selingan siap santap dan lebih praktis untuk dikonsumsi oleh pasien, (2) dalam berat per sajian yang sama (45 gram), kandungan zat gizi snack bar lebih mendekati standar sehingga memudahkan pasien untuk memenuhi kebutuhan zat gizinya, (3) meskipun snack bar memiliki rasio fosfor- protein lebih tinggi dibandingkan standar tetapi turut diimbangi dengan kandungan fosfor yang rendah sehingga menurunkan risiko peningkatan kadar fosfor dalam darah, dan (4) kandungan protein snack bar yang rendah dan nilai biologis protein yang tinggi dapat membantu penyerapan nitrogen serta menurunkan sisa hasil metabolisme protein yang dapat memperberat fungsi ginjal pasien. 


\section{SIMPULAN DAN SARAN Simpulan}

1. Semua formulasi snack bar secara umum telah memenuhi syarat kandungan zat gizi dalam satu takaran saji makanan selingan pasien GGK dengan hiperfosfatemia dan masih dapat diterima oleh panelis.

2. Rasio fosfor-protein terendah terdapat pada formulasi sereal beras yaitu $23,74 \mathrm{mg} / \mathrm{gram}$ diimbangi dengan kandungan fosfornya yang rendah yaitu $58,13 \mathrm{mg}$.

3. Daya patah yang rendah pada formulasi sereal beras menunjukkan lebih lembutnya tekstur snack bar dan lebih mudahnya dikunyah oleh pasien.

\section{Saran}

1. Pemberian alternatif pengganti buih putih telur seperti inulin sebagai upaya untuk menurunkan risiko peningkatan kadar fosfor dan rasio fosfor-protein dalam snack bar.

2. Snack bar yang direkomendasikan adalah formulasi sereal beras dengan kandungan protein 2,44 gram, lemak 5,81 gram, karbohidrat 33,20 gram, energi 194,78 kkal, fosfor $58,13 \mathrm{mg}$, dan rasio fosfor-protein 23,74 $\mathrm{mg} /$ gram dalam berat takaran saji 45 gram.

\section{DAFTAR PUSTAKA}

1. Prodjosudjadi Wiguno, Suharjono, Suwitra Ketut, Pranawa, Widiana I Gde Raka, Loekman Jodi Sidharta, et al. Detection and prevention of chronic kidney disease in Indonesia: Initial community screening [Abstract]. Asian Pasific Society of nephrology 2009; 14(7): 669-674.

2. National Kidney Foundation. K/DOQI clinical practice guidelines for bone metabolism and disease in chronic kidney disease. Am J Kidney Dis 2003; 42: Suppl 3: S63.

3. Shinaberger Christian S, Greenland Sander, Kopple Joel D, Wyck David Van, Mehrotra Rajnish, Kovesdy Csaba P, et al. Is controlling phosphorus by decreasing dietary protein intake beneficial or harmful in persons with chronic kidney disease? Am J Clin Nutr 2008; 88: 1511-8.

4. Snetselaar Linda G. Nutrition counseling skills for the nutrition care process $4^{\text {th }}$ ed. USA: Jones and Bartlett; 2009. Chapter 7, Nutrition counseling in treatment of renal disease; p.339

5. Helal Imed, Fick-Brosnahan Godela M, ReedGitomer Berenice Schrier Robert W. Glomerular hyperfiltration: definitions, mechanisms and clinical implications. Nat. Rev. Nephrol. 2012; 8, 293-300;

6. Wilkens Katy G, Juneja Veena. Medical nutrition therapy for renal disorders. In: Mahan L. Kathleen and Escott-Stump Sylvia. Krause's food and nutrition therapy. $12^{\text {th }}$ ed. Canada: Saunders; 2008. p. 922-923; 928.

7. Kalantar-Zadeh Kamyar, Gutekunst Lisa, Mehrotra rajnish, Kovesdy Csaba P, Bross Rachelle, Shinaberger Christian S, et al. Understanding sources of dietary phosphorus in the treatment of patients with chronic kidney disease. Clin J Am Soc Nephrol 2010; 5: 519-530.

8. Noori Nazanin, Kalantar-Zadeh Kamyar, Kovesdy Csaba P, Bross Rachelle, Benner Debbie, Koppie Joel D. Association of dietary phosphorus intake and phosphorus to protein ratio eith mortality in hemodialysis patients. Clin J Am Soc Nephrol 2010; 5: 683-692.

9. Mahmud Mien K, Zulfianto Nils Aria, editor. Tabel komposisi pangan Indonesia. Jakarta; PT Elex Media Komputindo; 2009. p.1

10. Ginmey Michael J, Lanham-New Susan A, Cassidy Aedin, Vorster Hester $\mathrm{H}$, editor. Introduction to human nutrition $2^{\text {nd }}$ ed. USA : A John Wiley \& Sons, Ltd. 2009.p.70

11. Noori Nazanin, Sims John J, Kopple Joel D, Shah Anuja, Colman Sara, Shinaberger Christian S. Organic and inorganic dietary phosphorus and its management in chronic kidney disease. Iranian Journal of Kidney Disease 2010; 4(2).

12. Karp H.J, Vaijia K.P, Karkkainen M.U.M, Niemisto M.J, Lamberg-Allardt C.J.E. Acute effects of different phosphorus sources on calcium and bone metabolism in young women: a whole-foods approach. Calcif Tissue Int 2007; 80:251-258.

13. Paraman Ilankovan, Wagner Michael E, Rizvi Syeh S.H. Micronutrient and protein-fortified whole grain puffed rice made by supercritical fluid extrusion. $\mathbf{J}$ Agric Food Chem 2012; 60: 11188-11194.

14. Hoke Karel, Hoousova Jirina, Houska Milan. Optimum conditions of rice puffing [Review]. Crech J Food Sci 2005; 23:1-11

15. Rafkin-Mervis Lisa E, Marks Jennifer B. The science of diabetic snack bar : A review. Clinical diabetes 2001; 19 (1).

16. USDA National Nutrient Database for Windows Search Software. Nutrient Data Laboratory, Release 24 [Software]. Agriculture Research Service; 2011.

17. Andarwulan Nuri, Kusnandar Feri, Herawati Dian. Analisis pangan. Jakarta: Dian Rakyat; 2011.p.9698, 123-125,155, 193-194.

18. Yusuf Nikmawatisusanti. Karakterisasi gizi dan pendugaan umur simpan savory chips ikan nike (Awaous melanocephalus) [Thesis]. Bogor: Sekolah Pasca Sarjana IPB; 2011.

19. Dwi S, Anton A, Maya PS. Analisis sensori untuk industri pangan dan agro. Bogor: IPB Press; 2010.

20. National Kidney Foundation. K/DOQI clinical practice guidelines for chronic kidneydisease: Evaluation, classification and stratification. Am J Kidney Dis 2002; 39: Suppl 1: 3,164 
21. Alias Abd Karim. Perkembangan hasilan makanan melalui teknologi ekstrusi. Pusat Pengajian Teknologi Industri Univesitas Sains Malaysia. 2006.

22. Muchtadi Tien R, Ayustaningwarno Fitriyono. Teknologi proses pengolahan pangan. Bandung: Alfabeta 2010.

23. National Kidney Foundation. Nutrition and chronic kidney disease (stages 1-4): Are you getting what you need?. New York: National Kidney Foundation Inc 2010.

24. Greiner Rafl, Konietzny Ursula. Phytase for food application. Food Technol. Biotechnol 2006; 44 (2) 125-140.

25. Muchtadi Tien R, Sugiyono, Ayustaningwarno Fitriyono. Ilmu pengetahuan bahan pangan $2^{\text {nd }}$ ed. Bogor: Alfabeta 2010.p.103

26. Kaur Narinder, Gupta Anil K. Applications of inulin and oligofructose in health and nutrition. J.Biosci 2002; 27. 703-714.
27. Kolida S, Tuohy K, Gibson G.R. Prebiotic effects of inulin and oligofructose. British Journal of Nutrition 2002; 87, Suppl. 2, S193-S197.

28. Onwulata C.I, Konstance R.P, Strange E.D, Smith P.W, Holsinger V.H. High fiber snack extruded from triticale and wheat formulations. U.S. Department of Agriculture, Agricultural Research Service 2000. Publication no. W-2000-0925-01R.

29. Ravi Ramasamy, Singh Vivek Kumar, Prakash Maya. Projective mapping and product positioning deep fat fried snack. Food and Nutrition Sciences 2011; 2. 674-683.

30. Wiratama, dkk. PKMP: Formulasi produk ekstrusi berbahan dasar sorgum: snack sehat, kaya serat dan antioksidan. Bogor : Ilmu Teknologi Pangan IPB 2010.

31. Dhanalakshmi K, Ghosal S, Bhattacharya S. Agglomeration of food powder and applications. Food Science and Nutrition 2011; 51. 432-44. 